\title{
The antioxidant effect of Jumbolan ethanolic extract seeds against carbon tetra chloride induced kidney toxicity in experimental rats.
}

\author{
Marwa Fawzy. A. EL-Hassanin \\ Lecturer in Nutrition and Food Science Dept., \\ Faculty of Home Economics, \\ AL-Azhar University, Egypt \\ Email: drmarwfawzy83@yahoo.com
}

\begin{abstract}
Abstract: The present work investigated the effects of Syzgium cumini L seeds ethanolic extract against carbon tetrachloride induced kidney toxicity in Sprague-Dawley male rats. Twenty four adult male albino rats were divided into two main groups: The first main group (6 rats) fed on basal diet as control negative group (C-ve). The second main group (18 rats) fed on basal diet for 28 days. At $27^{\text {th }}$ and $28^{\text {th }}$ days all rats were administrated ccl4 by gavage $(1 \mathrm{ml} / \mathrm{kgb} . \mathrm{w})$. The second main group was divided into 3 groups each group contained 6 rats as follows: Group 1: positive control, rats fed on basal diet only (C+ve). Group 2\&3: fed on basal diet and received jumbolan seeds extract (250 and $500 \mathrm{mg} \backslash \mathrm{kg}$ ) orally. At the end of the experiment biological data were calculated, blood samples were taken, kidney collected, weighted. Serum was separated to biochemical analysis. Tissue lipid peroxidation (LPX) and activity of antioxidant enzymes in kidney were also performed. Also histopathological examination for kidneys were performed. Results showed that $\mathrm{CCl} 4$ caused elevation in serum levels of creatinine, urea, uric acid, serum potassium, sodium, glucose and liver function. MDA level was also increased significantly whereas SOD, and CAT levels were decreased in the kidney tissue homogenates of $\mathrm{CCl} 4$ treated rats. Ethanolic extract of jumbolan seeds successfully improve the alterations of these effects in the experimental animals. Our study demonstrated that the ethanolic extract of jumbolan seeds could protect kidney tissues against $\mathrm{CCl} 4$-induced oxidative stress by increasing ant oxidative defense activities.
\end{abstract}

Key words: jumbolan, kidney, creatinine, uric acid, urea, catalase. 


\section{1-INTRODUCTION}

Exposure of diverse environment pollutants and xenobiotics such as alcohol, paracetamol, carbon tetrachloride (CCl4), thioacetamide are the major cause of liver disorder, which damage the liver and kidney by producing reactive oxygen species (Obogwu et al., 2014).

In years past, carbon tetrachloride was widely used as a dry cleaning solvent until it was recognized as a potent hepatotoxin, nephrotoxin and carcinogen. Today, it is primarily used as an organic solvent (Kovacic et al., 2002). Administration of $\mathrm{CCl} 4$ causes an increase in lipid peroxidation products (Daniels et al., 1995; Abraham et al., 1999 and Donder et al., 1999) and a decrease in the activity of enzymes protecting lipid peroxidation in the kidney (Dogukan et al., 2003). These detrimental effects of CCl4 have been attributed to conversion of $\mathrm{CCl} 4$ to highly toxic trichloromethyl and trichloromethyl peroxyl free radicals by cytochrome P450 enzyme, resulting in cell injury (Sundari et al., 1997; Abraham et al., 1999 and Bahcecioglu et al., 1999). Carbon tetrachloride (CCl4) is a halo alkane used in lots of industrial and chemical applications as a solvent for oils, fats, lacquers, varnishes and resins, as well as a primary material in the production of organic compounds. $\mathrm{CCl} 4$ is also a well-known toxin, which causes tissue damage in human and animals (Ogeturk et al., 2004; Babenko and Shakhova, 2008). Many studies have demonstrated that $\mathrm{CCl} 4$ could increase ceramide content in livers and kidneys (Ichi, et al., 2009).

Some studies have revealed that natural products، containing antioxidant, protect kidney against lipid peroxidation and impairment in antioxidant status induced by CCl4 (Khan et al., 2009). Jamshid et al., (2020) found that esveratrol shows a protective effect against nephrotoxicity in $\mathrm{CCl} 4$ treated rats by reducing oxidative stress status and modulating the TGF-beta signaling.

S. cumini is colloquially named as 'jamun' in India, 'black plum' in Europe, 'jambolan' in Spanish-speaking countries, and it is an evergreen tropical tree belonging to the family Myrtacea (Abhishek and Vindor, 2011). All parts of the tree can be used medicinally and it has a long history of use in traditional medicine (Baliga et al., 2011). Various traditional practitioners in the Indian subcontinent use the different parts of this tree in the treatment of a wide range of conditions, including diabetes, blisters in the mouth, cancer, colic, diarrhea, digestive complaints, dysentery, piles, pimples and stomachache (Rizvi and Mishra, 2013).

The seeds are reported to contain jamboline, traces of pale yellow essential oil, chlorophyll, fat, resin, albumen, tannins (Jadhav et al., 2009), phenolic 
compounds such as ellagic acid, gallic acid, caffeic and ferulic acids and their derivatives (Williamson, 2002) and flavonoids like rutin and quercetin (Sharma et al., 2008). Health-promoting activities of phenolic compounds present in jambolan reported as anti-inflammatory, anti-allergic, antihyperglycaemic, anticancer, cardioprotective, radioprotective, antibacterial, chemopreventive and antioxidant agents (Singh et al., 2018).

Based on such constituents, seed extracts are expected to possess excellent astringent and antioxidant potential, which may be beneficial in relieving gastroenteritis, liver and kidney inflammation. In the present study, CCl4 was used to induce oxidative stress in rats because of its well characterized mechanism, causing structural membranes damage and centrilobular necrosis. Therefore, this study was performed to investigate the protective effects of ethanolic jumbolan seeds extract onCCl4-induced oxidative stress, kidney injury in adult albino rat.

\section{2-MATERIALS AND METHODS}

\section{2/1 .Materials:}

-Jumbolan fruits were be obtained from a private farm in Tanta governorate.

-Sunflower oil and starch were purchased from the local market.

-Casein, cellulose, vitamins \& minerals, dextrin, L-cysteine, choline chloride, and $\mathrm{Ccl} 4$ were obtained from the Cairo Company for Chemical Trading, Cairo, Egypt.

-Twenty four male albino rats (Sprague Dawley strain) were obtained from the laboratory animal colony, Helwan, Cairo - Egypt. Weighting were approximately between $(150-180 \mathrm{~g})$.

\section{2/2. Methods:}

\section{2/2/1.Preparation of ethanolic seeds extract:}

Fruits were washed, after washed in water, the seeds were separated from their pulps and then dark dried for 5 days. The dried samples were ground to fine powder with electric grinder. About $100 \mathrm{~g}$ of jumbolan seeds was put in a $1 \mathrm{~L}$ beaker with $400 \mathrm{ml}$ ethanol $(95 \%)$, and the mixture was left overnight in the dark then the mixture was heated over mantel with continuous stirring for about 12 hrs. simmered for 10-15 minutes, then left to cool, steep covered for 10-15 minutes, and then the mixture filtered with filter paper. Finally the filtrate was left on the mantel to evaporate the solvent (ethanol) till near dryness. 


\section{2/2/2.Chemical composition of jumbolan seeds:}

Protein, fat, moisture, ash of seeds determined according to the methods of the A.O.A.C, (2010). Total carbohydrates will be calculated as following: Carbohydrates $\%=100-($ moisture $\%+$ protein $\%+$ fat $\%+$ ash $\%$ ).

\section{2/2/3.Determination of antioxidant activity for jumbolan seeds:}

Antioxidant activity determined by stable free radical diphenylpicrylhydrazyl (DPPH) Method to estimate the activity of antioxidants according to Santos et al (2013).

\section{2/2/4. Experimental design:}

Twenty four a dult male albino rats, Sprague Dawley strain, weighing (150-180g) used in this study were kept in wire cages. The diet was introduced to the rats in special food cups to avoid scattering of food. Also water was provided to the rats. Food and water were provided ad-libitum and checked daily. The rats were divided into two main groups: The first main group ( 6 rats) fed on basal diet as control negative group (C-ve). The second main group (18 rats) fed on basal diet for 26 days. At $27^{\text {th }}$ and $28^{\text {th }}$ all rats were administrated ccl 4 by gavage $(1 \mathrm{ml} / \mathrm{kgb} . \mathrm{w})$. This second main group was divided into 3 groups each group contained 6 rats as follows:-

Group 1: positive control, rats fed on basal diet only $(\mathrm{C}+\mathrm{ve})$.

Group 2: rats fed on basal diet and received jumbolan seeds extract $(250 \mathrm{mg} / \mathrm{kg})$.

Group 3: rats fed on basal diet and received jumbolan seeds extract $(500 \mathrm{mg} / \mathrm{kg})$ orally.

At the end of experiments, all rats were fasted overnight sacrificed and the blood samples were collected, a part of blood was centrifuged to obtain the serum. Internal organs were collected and removed (kidney, cleaned in saline solution, dried by filter paper and weighted. The left kidney was kept in formalin saline $10 \%$ for histopathological examination. The right kidney was kept at $-80^{\circ} \mathrm{C}$ for preparation of tissue homogenate for determination of antioxidant parameters. The homogenate was centrifuged at $10,000 \mathrm{rpm}$ for 20 min. The supernatant was used for the assay of some laboratory analyses.

\section{2/2/5.Biological evaluation:}

During the experimental period (28 day), the consumed diet was recorded everyday (feed intake), body weight was recorded every week and feed efficiency ratio (FER) (Chapman et al., 1959). 


\section{2/2/6. Biochemical analysis:}

Albumin, was determined according to (Drupt, 1974), total protein (Sonnenwirth and Jaret, 1980). Serum creatinine (Faulkner and King, 1976), serum uric acid (Fossati et al., 1980) and urea nitrogen (Patton and Crouch, 1977), sodium Henry (1974) and potassium Henry (1964). Total iron Siedel et al., (1984). ALP according to Kind and King (1954), aspartate amino transferase (AST) and alanine amino transferase (ALT) were determined according to Bergmeyer et al. (1986). Glucose (Trinder, 1959).

\section{2/2/7.Assessment of oxidant/antioxidant activity:}

Lipid peroxidation by thiobarbuturic acid-reactive substances (TBARS) (Uchiyama and Mihara 1978), Superoxide dismutase (SOD) by method developed by Misra and Fridovich (1972). Catalase (CAT) by colorimetric assay (Sinha, 1972).

\section{2/2/8.Statistical analysis:}

Data were presented as means \pm SD Statistical analysis of data were tested for significance using a one way analysis of variance (ANOVA) followed by Duncan's multiple range test using computerized SPSS program (Snedecor and Cochran 1986). Values were considered significant at $\mathrm{P}<0.05$.

\section{3-RESULTS:}

\section{3/1.Chemical composition of the Jumbolan seeds:}

Data presented in table (1) showed the averages g of moisture, protein, fat, carbohydrates, fiber and ash per $100 \mathrm{~g}$ Jumbolan seeds. The results of chemical compositions in seeds revealed that carbohydrates recorded the highest average followed by, fiber, moisture, protein, ash and fat respectively.

\section{Table 1. Proximate composition of the Jumbolan seeds (dry weight) (g\100 g seed)}

\begin{tabular}{|c|c|}
\hline Constituent & Seeds \\
\hline Moisture & $4.93 \pm 0.32 \mathrm{~g}$ \\
\hline Crude Protein & $2.74 \pm 0.01 \mathrm{~g}$ \\
\hline Crude Fiber & $7.67 \pm 0.12 \mathrm{~g}$ \\
\hline Fats/Oils & $1.016 \pm 0.36 \mathrm{~g}$ \\
\hline Ash & $2.67 \pm 0.12 \mathrm{~g}$ \\
\hline Carbohydrates & $80.097 \pm 0.53$ \\
\hline
\end{tabular}

$*$ Values are means \pm standard deviation of three determinations $(n=3)$ 


\section{3/2. The antioxidant activity $\%$ in jumbolan seeds extract}

The results in table (2) showed the average of antioxidant activity \% in jumbolan seeds. The results showed that average of antioxidant activity recorded $80.23 \%$.

Table 2. The average of antioxidant activity\% in jumbolan seeds extract

\begin{tabular}{|c|c|}
\hline sample & Antioxidant activity \\
\hline Jumbolan seeds & $80.23 \%$ \\
\hline
\end{tabular}

3/3. Effect of jumbolan seeds extract on body weight gain $\%$, feed intake, feed efficiency ratio and relative kidney weight in rats sufferinf from kidney toxicity.

Data presented in table (3) showed the effect of jumbolan seeds extract on body weight gain (BWG), feed intake (FI), feed efficiency ratio (FER) and relative kidney weight against carbon tetra chloride induced kidney toxicity in rats. The results showed that there was significant decrease for weight gain, feed intake and feed efficiency ratio in positive control group compared with negative group, while jumbolan seeds extract $(250 \& 500 \mathrm{mg} / \mathrm{kg}$ ) groups showed a significant increase in body weight gain, feed intake feed efficiency ratio compared with positive group $(\mathrm{p}<0.05)$. Data in this table revealed that there was a significant decrease in relative kidney weight for carbon tetra chloride group compared with normal control group. Also jumbolan seeds extract $(250 \& 500)$ groups showed improvement in relative kidney weight $(.737 \pm .05 \& .718 \pm .04)$ respectively compared with positive group $(\mathrm{p}<0.05)$.

Table 3. The effect of jumbolan seeds extract on BWG \%, FI, FER and relative Kidney weight against carbon tetra chloride induced kidney toxicity in rats

\begin{tabular}{|c|c|c|c|c|}
\hline \hline Parameters & BWG \% & $\begin{array}{c}\text { FI (g/day } \\
\text { rat) }\end{array}$ & FER \% & $\begin{array}{c}\text { Relative } \\
\text { Kidney } \\
\text { Weight }\end{array}$ \\
\hline \hline Control(-) & $24.22+1.3^{\mathrm{a}}$ & $18.75+0.38^{\mathrm{a}}$ & $0.10+0.009^{\mathrm{a}}$ & $.806 \pm .03^{\mathrm{a}}$ \\
\hline \hline Control(+) & $18.98+0.77^{\mathrm{b}}$ & $16.71+0.32^{\mathrm{b}}$ & $0.06+.003^{\mathrm{b}}$ & $.630 \pm .033^{\mathrm{c}}$ \\
\hline \hline Seeds extract (250) & $20.83+0.46^{\mathrm{a}}$ & $18.91+0.22^{\mathrm{a}}$ & $0.08+0.002^{\mathrm{a}}$ & $.737 \pm .05^{\mathrm{ab}}$ \\
\hline \hline Seeds extract (500) & $22.35+0.78^{\mathrm{a}}$ & $18.76+.26^{\mathrm{a}}$ & $0.09+0.004^{\mathrm{a}}$ & $.718 \pm .04^{\mathrm{b}}$ \\
\hline
\end{tabular}

Values denote arithmetic means \pm SD of the mean. Means with different letters (in the same column are significantly at $(\mathrm{p} \leq 0.05)$ using one way ANOVA test, while those with similar letters are non-significant. 


\section{3/4. Effect of jumbolan seeds extract on Kidney functions in rats suffering from kidney toxicity.}

Data in table (4), showed that administration of carbon tetra chloride increased the values of creatinine, uric acid and urea significantly as compared to negative control group. while treated groups with $(250 \& 500 \mathrm{mg}$ jumbolan seeds extract $\mathrm{kg}$ ) showed significant decreases in creatinine, uric acid and urea compared to positive control group. The best result was in jumbolan seeds extract $(500 \mathrm{mg} / \mathrm{kg})$.

Table 4. The effect of jumbolan seeds extract on serum creatinine, uric acid and urea against carbon tetra chloride induced kidney toxicity in rats

\begin{tabular}{||c||c||c||c||}
\hline groups parameters & $\begin{array}{c}\text { Creatinine } \\
(\mathbf{m g} / \mathbf{d l})\end{array}$ & $\begin{array}{c}\text { Uric acid } \\
(\mathbf{m g} / \mathbf{d l})\end{array}$ & $\begin{array}{c}\text { urea } \\
(\mathbf{m g} / \mathbf{d l})\end{array}$ \\
\hline \hline Control(-) & $.286 \pm .04^{\mathrm{c}}$ & $2.25 \pm .35^{\mathrm{c}}$ & $14.53 \pm 1.82^{\mathrm{c}}$ \\
\hline \hline Control(+) & $.625 \pm .10^{\mathrm{a}}$ & $5.56 \pm .45^{\mathrm{a}}$ & $24.16 \pm 1.16^{\mathrm{a}}$ \\
\hline \hline Seeds extract (250) & $.393 \pm .09^{\mathrm{b}}$ & $2.36 \pm .33^{\mathrm{c}}$ & $17.41 \pm 1.68^{\mathrm{b}}$ \\
\hline \hline Seeds extract (500) & $.371 \pm .07^{\mathrm{bc}}$ & $2.53 \pm .22^{\mathrm{c}}$ & $14.76 \pm 2.46^{\mathrm{c}}$ \\
\hline
\end{tabular}

Values denote arithmetic means \pm SD of the mean. Means with different letters (in the same column are significantly at $(\mathrm{p} \leq 0.05)$ using one way ANOVA test, while those with similar letters are non-significant.

\section{3/5. Effect of jumbolan seeds extract on serum sodium, potassium and iron in rats suffering from kidney toxicity.}

Table (5) illustrated the results of serum electrolytes of negative control group, positive control group and treated groups with (jumbolan seeds extract $250 \& 500 \mathrm{mg} / \mathrm{kg}$ ). Mean value of sodium and potassium in positive control group were significant increased as compared to negative control group .All treated groups with (jumbolan seeds extract $250 \& 500 \mathrm{mg} / \mathrm{kg}$ ) showed significant decreases as compared to positive control group. Total iron recorded a significant decrease in rats administrated carbon tetra chloride compared to normal control group. Whereas, there were a significant increase in treated groups compared to positive control group. 
Table 5. The effect of jumbolan seeds extract on serum sodium, Potassium and total iron against carbon tetra chloride induced kidney toxicity in rats

\begin{tabular}{|c||c|c||c|}
\hline groups parameters & $\begin{array}{c}\text { Sodium } \\
(\mathbf{m m o l} / \mathbf{l})\end{array}$ & $\begin{array}{c}\text { Potassium } \\
(\mathbf{m m o l} / \mathbf{l})\end{array}$ & Total iron $\boldsymbol{\mu g} / \mathbf{d L}$ \\
\hline \hline Control(-) & $144.83 \pm 2.99^{\mathrm{b}}$ & $6.8 \pm .33^{\mathrm{b}}$ & $142.33 \pm 0.06^{\mathrm{a}}$ \\
\hline \hline Control(+) & $155.50 \pm 3.01^{\mathrm{a}}$ & $8.13 \pm .25^{\mathrm{a}}$ & $101.83 \pm 0.04^{\mathrm{d}}$ \\
\hline \hline Seeds extract (250) & $144.16 \pm .75^{\mathrm{b}}$ & $6.10 \pm .77^{\mathrm{b}}$ & $122.83 \pm 0.02^{\mathrm{c}}$ \\
\hline \hline Seeds extract (500) & $143.50 \pm 2.42^{\mathrm{bc}}$ & $6.20 \pm .93^{\mathrm{b}}$ & $138.17 \pm 0.06^{\mathrm{b}}$ \\
\hline \hline
\end{tabular}

Values denote arithmetic means \pm SD of the mean. Means with different letters (in the same column are significantly at $(\mathrm{p} \leq 0.05)$ using one way ANOVA test, while those with similar letters are non-significant.

3/5. Effect of jumbolan seeds extract on serum protein, albumin and glucose in rats suffering from kidney toxicity.

Table (6) depicts that the serum levels of total protein; albumin were significantly lowered in carbon tetra chloride treated group $(+v e)$ in comparison to control group (-ve).Treated groups significantly increased the levels of serum protein. The results obtained indicated that the $\mathrm{CCl} 4$ intoxicated group revealed a high significant increase in the mean value of serum glucose $(255.50+22.24$ $\mathrm{mg} / \mathrm{dl})$ as compared with the normal group $(82.05+10.46 \mathrm{mg} / \mathrm{dl})$. The serum glucose of the treated groups were $(92.20+3.74$ and $78.17+1.94 \mathrm{mg} / \mathrm{dl})$, which were very close to the normal group.

Table 6. The effect of jumbolan seeds extract on serum total protein, albumin and glucose against carbon tetra chloride induced kidney toxicity in rats

\begin{tabular}{|c||c|c||c|}
\hline groups & $\begin{array}{c}\text { Total protein } \\
(\mathbf{g} / \mathbf{d l})\end{array}$ & $\begin{array}{c}\text { Albumin } \\
(\mathbf{g} / \mathbf{d l})\end{array}$ & Glucose(mg/dl) \\
\hline \hline Control(-) & $5.53 \pm .27^{\mathrm{ab}}$ & $3.54 \pm .23^{\mathrm{a}}$ & $82.05 \pm 10.46^{\mathrm{cb}}$ \\
\hline \hline Control(+) & $4.026 \pm .10^{\mathrm{c}}$ & $2.96 \pm .16^{\mathrm{b}}$ & $255.50 \pm 22.24^{\mathrm{a}}$ \\
\hline \hline Seeds extract (250) & $5.59 \pm .27^{\mathrm{a}}$ & $3.70 \pm .06^{\mathrm{a}}$ & $92.20 \pm 3.74^{\mathrm{c}}$ \\
\hline \hline Seeds extract (500) & $5.12 \pm .36^{\mathrm{b}}$ & $3.27 \pm .71^{\mathrm{ab}}$ & $78.17 \pm 1.94^{\mathrm{b}}$ \\
\hline
\end{tabular}

Values denote arithmetic means \pm SD of the mean. Means with different letters (in the same column are significantly at $(\mathrm{p} \leq 0.05)$ using one way ANOVA test, while those with similar letters are non-significant. 


\section{3/6. Effect of jumbolan seeds extract on liver enzymes in rats suffering from kidney toxicity.}

Results illustrate that Alanine transaminase (ALT), Aspartate aminotransferase (AST) and Alkaline phosphatase (ALP) enzymes activity significantly increased in positive group (+ve) compared with (-ve) control group. While jumbolan seeds extract $(250 \& 500)$ groups reduced these enzymes activity when compared with $(+v e)$ group, respectively.

Table7. The effect of jumbolan seeds extract on serum (ALT, AST, and ALP) against carbon tetra chloride induced kidney toxicity in rats

\begin{tabular}{|c||c||c|c|}
\hline parameters & $\begin{array}{c}\text { AST } \\
\text { (U/L) }\end{array}$ & $\begin{array}{c}\text { ALT } \\
(\mathbf{U} / \mathbf{L})\end{array}$ & $\begin{array}{c}\text { ALP } \\
(\mathbf{U} / \mathbf{L})\end{array}$ \\
\hline \hline Control(-) & $48.50 \pm 0.1^{\mathrm{a}}$ & $22.80 \pm 0.10^{\mathrm{a}}$ & $146 \pm 1.00^{\mathrm{a}}$ \\
\hline \hline Control(+) & $79.50 \pm 0.10^{\mathrm{c}}$ & $34.50 \pm 0.10^{\mathrm{c}}$ & $383 \pm 1.00^{\mathrm{d}}$ \\
\hline \hline Seeds extract (250) & $53.30 \pm 0.10^{\mathrm{b}}$ & $29.50 \pm 0.10 \mathrm{~b}$ & $263 \pm 1.00^{\mathrm{c}}$ \\
\hline \hline Seeds extract (500) & $55.60 \pm 0.10^{\mathrm{b}}$ & $27.50 \pm 0.10^{\mathrm{b}}$ & $222 \pm 1.00 \mathrm{~b}$ \\
\hline \hline
\end{tabular}

Values denote arithmetic means \pm SD of the mean. Means with different letters (in the same column are significantly at $(\mathrm{p} \leq 0.05)$ using one way ANOVA test, while those with similar letters are non-significant.

\section{3/7.Antioxidant SOD, CAT and lipid peroxide (MDA) in kidney tissue:}

From (table7) as a result of administering Ccl4,there were a marked reduction in the levels of some antioxidants in the kidney tissue such as catalase (CAT) and superoxide dismutase (SOD), in carbon tetra chloride group $(+\mathrm{ve})$ as compared to negative control group. Also, administration of Ccl4 stimulated lipid peroxidation as estimated by a significant elevation in lipid peroxidation by-product malondialdehyde (MDA). Jumbolan seeds extract $(250 \& 500 \mathrm{mg} / \mathrm{kg})$ reduced the levels of MDA and stimulated antioxidant activity in kidney tissue compared to $(+\mathrm{ve})$ group. 
Table 8. The effect of jumbolan seeds extract on antioxidant SOD, CAT and lipid peroxide (MDA) in kidney tissue against carbon tetra chloride induced kidney toxicity in rats

\begin{tabular}{|c|c|c|c||}
\hline parameters & $\begin{array}{c}\text { (nmol } \backslash \mathbf{m g}) \\
\text { MDA/gm. } \\
\text { kidney tissue }\end{array}$ & $\begin{array}{c}\text { (Unit) SOD } \\
\text { (ulmg) } \\
\text { kidney tissue }\end{array}$ & $\begin{array}{c}\text { CAT (ng\mg) } \\
\text { kidney tissue }\end{array}$ \\
\hline \hline Control(-) & $.082 \pm .01^{\mathrm{a}}$ & $.220 \pm .02^{\mathrm{d}}$ & $.224 \pm .02^{\mathrm{cd}}$ \\
\hline \hline Control(+) & $.242 \pm .03^{\mathrm{d}}$ & $.113 \pm .01^{\mathrm{a}}$ & $.075 \pm .01^{\mathrm{a}}$ \\
\hline \hline Seeds extract (250) & $.163 \pm .01^{\mathrm{c}}$ & $.127 \pm .02^{\mathrm{b}}$ & $.140 \pm .01^{\mathrm{b}}$ \\
\hline \hline Seeds extract (500) & $.167 \pm .02^{\mathrm{c}}$ & $.180 \pm .01^{\mathrm{bc}}$ & $.167 \pm .01^{\mathrm{c}}$ \\
\hline \hline
\end{tabular}

Values denote arithmetic means \pm SD of the mean. Means with different letters (in the same column are significantly at $(\mathrm{p} \leq 0.05)$ using one way ANOVA test, while those with similar letters are non-significant.

\section{3/8.Histopathological examination of kidneys:}

Samples taken from the kidneys of rats in all groups processed for paraffin embedding. The samples were cut into $4-\mu \mathrm{m}$ histological sections, which were stained with Masson's trichrome and examined under light microscopy. The light microscopic examination of normal control (-) group kidney sections (photo 1) showed normal orientation of nephrons with adequate glomeruli and well-spaced tubules and no inflammation, no necrosis, no congestion. It is clear that from photo (2) represented that the light microscopic examination of injured group which received carbon tetra chloride at the end of experiment there were characteristic of acute tubular necrosis, tubular cell necrosis; moderate tubular lumen dilation; marked foci of denuded basement membrane; mild intraluminal casts; swelling/flattening of proximal tubular cells with brush border loss; diffuse interstitial edema; interstitial inflammatory cell infiltrates. Photo (3) showed that the light microscopic examination of kidney sections for rats which received jumbolan seeds extract $250 \mathrm{mg} / \mathrm{kg}^{-1} / \&$ carbon tetra chloride there were tubular cell necrosis; nil (no) tubular lumen dilation; moderate foci of denuded basement membrane; mild intraluminal casts; nil swelling/flattening of proximal tubular cells with brush border loss; mild diffuse interstitial edema; nil interstitial inflammatory cell infiltrates: mild. Also Photo (4) showed that tubular cell necrosis; mild tubular lumen dilation; mild foci of denuded basement membrane; mild intraluminal casts; nil swelling/flattening of proximal tubular cells with brush border loss; mild diffuse interstitial edema; nil interstitial inflammatory cell infiltrates: mild in rats received jumbolan seeds extract $500 \mathrm{mg} / \mathrm{kg}^{-1} / \&$ carbon tetra chloride. 


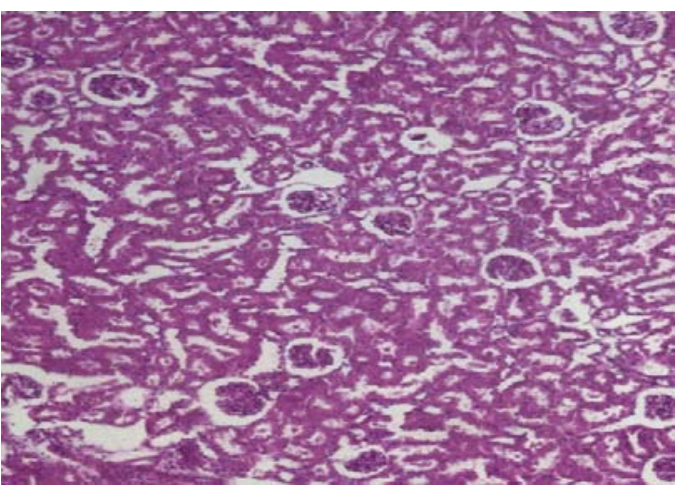

Photo (1): Kidney section from control (-) group of normal rats received basal diet and tab water showed normal orientation of nephrons with adequate glomeruli and wellspaced tubules (H\&E,x100).

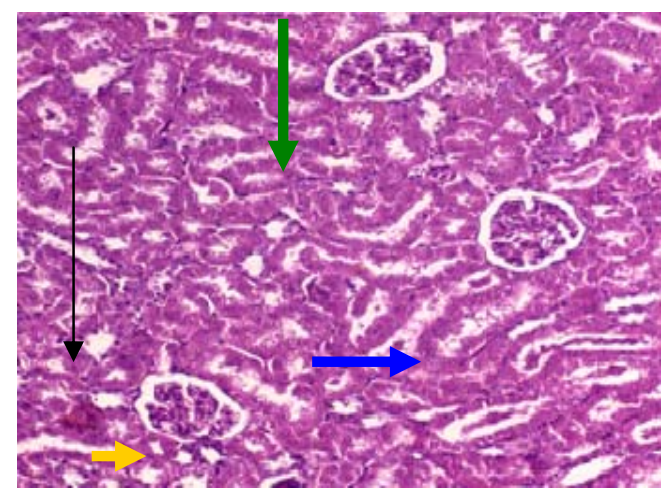

Photo(4): treated group showed: tubular cell necrosis (blue arrow); tubular lumen dilation (yellow arrow); foci of denuded basement membrane, intraluminal casts (red arrow) ;swelling/flattening of proximal tubular cells with brush border loss (green arrow) and interstitial inflammatory cell infiltrates (black arrow)

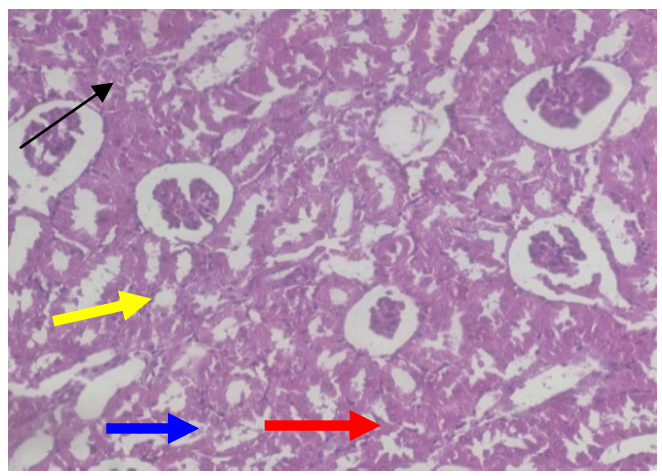

Photo(3): treated group showed: tubular cell necrosis (blue arrow); tubular lumen dilation (yellow arrow); foci of denuded basement membrane; swelling/ flattening of proximal tubular cells with brush border loss (green arrow); and interstitial inflammatory cell infiltrates (black arrow) (H\&E,x100,x200). (green arrow); diffuse interstitial and interstitial inflammatory cell infiltrates (black long arrow) (H\&E,x100,x200). 


\section{4- DISCUSSION:}

In this study, we hypothesized that ethanolic seeds extract of Syzgium cumini $L$ would effectively protect kidneys by its antioxidant and antiinflammatory effects on CCl4-induced injury. The present study demonstrated that ethanolic jumbolan seeds extract inhibited CCl4-induced oxidative stress, inflammation and apoptosis probably through regulating ceramide, MAPKs, calpain and mitochondrial pathway.

Binita et al., (2017) found that seeds are moderately rich in protein (6.3$8.5 \%$ ) and contains so many other phytochemicals. In the current study, CCl4 induced kidney toxicity in rats and consequently decreased BWG \% which also accompanied with decreased FER compared with negative control group. Lee et al., (2007) and Khan et al., (2012) reported that injection of Ccl4 was significantly decreased body weight gain and food intake.

Feed intake and body weight gain was significantly increased in rats had received jumbolan seeds extract $(250 \mathrm{mg} / \mathrm{kg}) \&(500 \mathrm{mg} / \mathrm{kg})$. These may be due to presence of polyphenols which present in jumbolan seeds while improve and protect liver cells against damage via increasing both the levels and activities of antioxidant enzymes in liver and kidneys according to (Jachec et al., 2002) leading to improvement the appetite and increasing feed intake. Relative kidney weight decreased in rats treated with $\mathrm{CCl} 4$ and increased in rats treated with jumbolan seeds. Mechanism of CCl4-induced damage in kidneys is by causing inflammatory response. Excessive ROS induced by $\mathrm{CCl} 4$ could also lead to increased inflammatory cytokines production (Ma et al., 2015). (Jie-Qiong Maa et al., (2018) found that mice receiving $\mathrm{CCl} 4$ alone showed kidney injury as evidenced by elevation in serum biochemical markers, inflammation, caspase-3 activity and apoptosis in kidney. These changes may occur due to the reduction in the glomerular filtration rate (GFR) or may be secondary due to the oxidative stress, which can cause contraction of mesangial cells, alteration of filtration surface area, and modification of the ultrafiltration coefficient factors that thereby reduces GFR (Saikat Sen et al., 2018).

These data suggests that jumbolan seeds extract was effective in reduction of blood urea, creatinine, and uric acid levels in rats with kidney damage induced by ccl4. Nahid et al., (2016) found that jumbolan seeds extract reduced uric acid, creatine phosphokinase, and lactate dehydrogenase. Ayyanar and Subash-Babu (2012) documented that jambolan seeds contained phenolic acids, flavonoids and tannins. Jumbolan seeds contain myricetin, quercetin, rutin, ellagic acid and gallic acid have been reported to be effective on kidney injury. 
The administration of ccl4 significantly increased the serum sodium and potassium concentration, decreased total iron in rats. Toxic chemicals, certain drugs, infectious agents can induce damage to the kidney that ultimately leads to the imbalance of electrolyte (Rajakrishnan et al., 2017). Also in my study it could be noticed that rats treated with ccl4 had an increase in hepatic enzymes, glucose and a decrease in total protein and albumin when compared with negative control group. Histology of the $\mathrm{CCl} 4$ treated group revealed inflammation and damage of liver cells. Islam et al., (2015) concluded that methanol extract of seeds of Syzygiumcumini, increased serum protein level in $\mathrm{CCl} 4$ treated group. Binita et al., (2017) mentioned that seeds are rich with phytochemicals. These phytochemicals may provide versatile benefits by influencing biological pathways and improve the diabetic symptoms. Also, liver protective activity of the extract was attributed to saponins, tannins and flavonoids. In the present study, administration of ethanolic extract of seeds of the plant in two doses lowered the level of biochemical markers, which were increased by free radicals of CCl4. It is probable that the administration of extract for 28 days increased the antioxidant capacity of animal to scavenge the free radicals generated by $\mathrm{CCl} 4$.

Also my results also showed that $\mathrm{CCl} 4$ caused a marked increase in MDA levels whereas SOD and CAT levels were decreased in kidney tissue homogenates of $\mathrm{CCl} 4$ treated rats. Ethanolic seeds extract successfully prevented the alterations of these effects in the experimental animals. These findings are in line with those of Shereen et al., (2015) and Rahmouni et al., (2017). $\mathrm{CCl} 4$ when administrated is distributed and deposited to organs such as the liver, brain, kidney, lung and heart. The reactive metabolite trichloromethyl radical $(\cdot \mathrm{CCl} 3)$ and trichloromethyl peroxide radical $(\mathrm{CCl} 3 \mathrm{O} 2 \cdot)$ has been formed from the metabolic conversion of $\mathrm{CCl} 4$ by cytochrome P-450. As O2 tension rises, a greater fraction of $\cdot \mathrm{CCl} 3$ present in the system reacts very rapidly with $\mathrm{O} 2$ and more reactive free radicals, like $\mathrm{CCl} 3 \mathrm{OO} \cdot$ is generated from $\bullet \mathrm{CCl} 3$. These free radicals initiate the peroxidation of membrane poly unsaturated fatty acids (PUFA), cell necrosis, GSH depletion, membrane damage and loss of antioxidant enzyme activity. Jumbolane seeds were be antitumor and antioxidative (Goyal et al., 2010). And (Arun et al., 2011).

Seeds are known to contain ellagic acid, gallic acid and quercetin. Healthpromoting activities of phenolic compounds present in jambolan reported as anti-inflammatory, anti-allergic, antihyperglycaemic, anticancer, cardioprotective, radioprotective, antibacterial, chemopreventive and antioxidant agents (Singh et al., 2018). 


\section{5- CONCLUSSION}

Jumbolan seeds have high contents of bioactive phytochemicals, such as phenolic acids, condensed tannins, and flavonoids, including ellagic acid, gallic acid and quercetin which improve liver function and kidney toxicity against carbon tetra chloride.

\section{RFERENCES}

Abhishek, K.S. \& Vinod, K. V. (1972). Quantitative enzymatic colorimetric determination of uric acid in serum.; plasma or urine. Analyst, 97,142.

Abraham, P., Wilfard, G., Cathrine, S.P., (1999). Oxidative damage total lipids and proteins of the lungs, testis and kidney of rats during carbon tetrachloride intoxication. Clin. Chim. Acta 289, 177-179.

A.O.A.C. (2005): Official methods of analysis of the association of official analytical chemistry, $15^{\text {th }}$ ed. Washington, D.C.

Arun, R., Parkash, M. V., Abraham, S. K., and Premkumar, K. (2011): Role of Syzygium cumini seed extract in the chemoprevention of in vivo genomic damage and oxidative stress. J. Ethnopharmacol. 134, 329-333.

Ayyanar, M. \& Subash-Babu, P. (2012). Syzygium cumini (L.) Skeels: A review of its phytochemical constituents and traditional uses. Asian Pacific Journal of tropical Biomedicine, 2, 240-246.

Babenko, N.A. and Shakhova, E.G. (2008):Effects of flavonoids on sphingolipid turnover in the toxin-damaged liver and liver cells, Lipids Health Dis. 7 .24-35.

Bahcecioglu, I.H., Ustundag, B., Ozercan, I., Ercel, E., Baydas, G.,Akdere, T. and Demir, A., (1999). Protective effect of Ginkgo biloba extract on CCI4induced liver damage. Hepatology Research 15, 215-224.

Baliga MS, Bhat HP, Baliga BRV, Wilson R and Palatty PL (2011): Phytochemistry, traditional uses and pharmacology of Eugenia jambolana Lam. (black plum): a review. Food Res Int ; 44(7): 1776-89. 
Bergmeyer, H. U., Herder, M. and Rej, R. (1986) : Approved Recommendation (1985) on IFCC Methods for the Measurement of Catalytic Concentrations of nzymes. Part 3. IFCC Method for Alanine Aminotransferase. J. Clin. Chem. Clin. Biochem. 24, 81-495.

Binita, K., Sharma,V and Yadav,S.(2017): The therapeutic potential of Syzygium cumini seeds in diabetes mellitus., Journal of Medicinal Plants Studies ; 5(1): 212-218.

Chapman, D.G., Castilla, R. and Campbell, J.A. (1959): Evaluation of protein in food. I. A method for determination of protein efficiency ratio. Can. J. Biochem. Physiol., 37: 679-689.

Daniels, W.M., Reiter, R.J., Melchiorri, D., Sewerynek, E., Pablos, M.I., Ortiz, G.G( 1995) :Melatonin counteracts lipid peroxidation induced by carbon tetrachloride but does not restore glucose- 6 phosphatase activity. Journal of Pineal Research 19, 1-6.

Dogukan, A., Akpolat, N., Celiker, H., Ilhan, N., Bahcecioglu, I.H and Gunal, A.I., (2003): Protective effect of interferon-on carbon tetrachlorideinduced nephrotoxicity. Journal of Nephrology 16,81-84.

Donder, E., Baydas, G., Ozkan, Y., Ercel, E., Yalniz, M and Dogan, H., (1999): Investigation of antioxidant effect of melatonin against carbon tetrachloride toxicity in various tissues. Biomedical Research 10,141-145.

Drupt, F. (1974): Colorimetric method for determination of albumin. Pharm. Biol., 9: 777-779.

Faulkner, N.R. and King, J.W. (1976): Fundamental of Clinical Chemistry. 2 ed. Tietz, Editor. Saunders Philadelphia, pp: 994- 998.

Fossati, P., Prenciple, L. and Berti, G. (1980): Enzymatic colorimetric method for determination of uric acid in serum. Clin. Chem., 26, 227-273.

Goyal, P.K., Verma, P., Sharma, P., Parmar, J. \& Agarwal, A. (2010). Evaluation of anti-cancer and anti-oxidative potential of Syzygium cumini against benzo [a] pyrene $(\mathrm{BaP})$ induced gastric carcinogenesis in mice. Asian Pacific Journal of Cancer Prevention, 11, 753-758. 
Henry, R.J. (1964): Colorimetric method of total protein. J. of Clinical Chemistry, Harper, Row Publishers, New York. P. 181.

Henry, R.J. (1974): Clinical Chemistry Principles and Techniques. $2^{\text {nd }}$ E.D., Harper and Publishers, New York. Philadelphia.

Ichi, I. . Kamikawa, C Nakagawa, T. Kobayashi, K. Kataoka, R. Nagata, E. Kitamura, Y. Nakazaki, C. Matsura, T. and Kojo, S. (2009): Neutral sphingomyelinase-induced ceramide accumulation by oxidative stress during carbon tetrachloride intoxication, Toxicology $261: 33-40$.

Islam M, K Hussain, A Latif, FK Hashmi, H Saeed, NI Bukhari, SS Hassan, MZ Danish and B Ahmad. (2015). Evaluation of extracts of seeds of Syzygium cumini L. for hepatoprotective activity using CCl4-induced stressed rats. Pak Vet J, 35(2): 197-200.

Jachec, W., Tomasik, A. Tarnawski, R. and Chwalinska, E. (2002): Evidence of oxidative stress in the renal cortex of diabetic rats: Favourable effect of vitamin E. Scandinavian Journal of Clinical and Laboratory Investigation, (62), 81-88.

Jadhav VM, SS Kamble and VJ Kadam, 2009. Herbal medicine: Syzygium cumini: A Review. J Pharm Res, 2: 1212-1219.

Jamshid,K., Saeed,M ., Eidar,T ., Iraj,K and Mohseni,,M.and

Mohammad,H (2020). Resveratrol downregulates $T G F-\beta 1$ and Smad3 expression and attenuates oxidative stress in CCl4-induced kidney damage in rats. Asian Pacific Journal of Tropical Biomedicine, 10 (9). p. 397. ISSN 22211691

Jie-QiongMaa., Chan-Min Liub and Wei Yangb (2018): Protective effect of rutin against carbon tetrachloride-induced oxidative stress, inflammation and apoptosis in mouse kidney associated with the ceramide, MAPKs, p53 and calpain activities. Chemico-Biological interactions, 286, 26-33.

Lee, H. S.; Keum, K. Y. and Ku, S. K. (2007): Effects of picrorrhiza rhizome water extracts on the subacute liver damages induced by carbon tetrachloride. J. Med. Food., 10(1): 110-117. 
Ma, Z. Li, W.R. Xie, C.M. Liu, S.S. Liu,(2015): Quercetin protects mouse liver against CCl4-induced inflammation by the TLR2/4 and MAPK/NF- $\kappa B$ pathway, Int.Immunopharm. $28: 531-539$.

Khan, M.R., Khan, G.N. and Ahmed, D. (2011): Evaluation of antioxidant and fertility effects of Digera muricata in male rats. Afr J Pharm Pharmacol, 5(6):688-699.

Kind, P.R. and King, E.J. (1954): Estimation of alkaline phosphatase activity by determination of hydrolyzed phenol with aminoantipyrene. J. Clin. Path., 7(4): 322-326.

Ko, KM., Ip, SP., Poon, MK., Wu, SS., Che, CT., Ng, KH and Kong C.(1995): Effect of a ligninenriched fructus schisandrae extract on hepatic glutathione status in rats: protection against carbon tetrachloride toxicity. Planta Med, 61:134-137.

Kovacic, P., Sacman, A. and Wu-Weis, M., (2002) :Nephrotoxins: widespread role of oxidative stress and electron transfer. Current Medicinal Chemistry 9, 823-847.

Misra, H.P and Fridovich, I. (1972): The role of superoxide anion in the autoxidation of epinephrine and a simple assay for superoxide dismutase. J Biol Chem. 25;247(10):3170.

Nahid S, Mazumder K, Rahman Z, Islam S, Rashid MH, Kerr PG, (2016):Cardio- and hepato-protective potential of methanolic extract of Syzygium cumini (L.) Skeels seeds: A diabetic rat model study, Asian Pacific Journal of Tropical Biomedicine, doi: 10.1016/j.apjtb.2016.11.025.

Obogwu M, Akindele A and Adeyemi O.(2014): Hepatoprotective and in vivo antioxidant activities of the hydroethanolic leaf extract of mucuna pruriens (Fabaceae) in antitubercular drugs and alcohol models. CJNM;12(4):273-83.

Ogeturk, M., Kus, I. . ,Kavakli, A .,Zararsiz, I. , Ilhan, N and Sarsilmaz, M..(2004): Effects of melatonim on carbon tetrachloride-induced chananges in rat serum, J. Physiol. Biochem. 60;205-210.

Patton, C.J. and Crouch, S.R. (1977): Enzymaticcolorimetric method for determination of urea inserum. Anal. Chem., 49, 464-469. 
Rahmouni, F, Hamdoui, L, Badraoui, R and Rebai, T. (2017: Protective effects of Teucriumpolium aqueous extract and ascorbic acid on hematological and some biochemical parameters against carbon tetrachloride (CCl4) induced toxicity in rats. Biomed \& Pharmacother. 91, 43-48.

Rajakrishnan, R., Lekshmi, R., Benil, P. B., Thomas, J., AlFarhan, A. H, Rakesh, V., and Khalaf, S. (2017): Phytochemical evaluation of roots of Plumbagozylanica L. and assessment of its potential as anephroprotective age. Saudi J Bio Sci. 24 (4), 760-6.

Rizvi, S.I, and Mishra, N.(2013): Traditional Indian medicines used for the management of diabetes mellitus. J Diabetes Res 2013; 2013: 712092.

Saikat Sen,S., Chakraborty,R and Kalita,P.(2018): Dillenia indica fruit prevents cisplatin-induced kidney injury in experimental rats through modulation of oxidative stress, marker enzyme, and biochemical changes,Nutrire.,43:15.

Santos, D.T., Cavalcanti, R.N., Rostagno, M.A., Queiroga, C.L.,Eberlin, M.N. \& Meireles, M.A.A. (2013). Extraction of polyphenols and anthocyanins from the jambul (Syzygium cumini) fruit peels. Food and Public Health, 3, 1220.

Sharma, B., Balomajumder, $C$ and Roy, P. (2008). Hypoglycemic and hypolipidemic effects of flavonoid rich extract from Eugenia jambolana seeds on streptozotocin induced diabetic rats. FoodChem Toxicol, 46: 2376-2383.

Shereen, S., Rashid Khan, M., Ali Khan, R., Mohammad and Alkreathy. H. (2015): Protective effects of Carissa opaca fruits against CCl4-induced oxidative kidney lipid peroxidation and trauma in rat. Food Nut. Res.59,10.

Siedel,J.; Wahlefeld, A.W. and Ziegenhorn,J.(1984):A new iron ferrozine reagent without deporteinization.Clin .Chem., 30:975.

Singh,B ., Singh,J.P , Kaur ,A and Singh,N .(2018): Insights into the phenolic compounds present in jambolan (Syzygium cumini) along with their health-promoting effects. Food Science \& Technology; 53, 11 2431-2447.

Sinha, A.K. (1972): Colorimetric assay of catalase, Analytical Biochemistry, 47:2:389-394. 
Snedecor, G.W. and W.G. Cochran. (1986): Statistical Methods, 4 ed. Iowa State University Press, Ames,Iowa, USA, pp: 91.

Sonnenwirth, A. and L. Jaret. (1980): Grad Wholes Clinical Laboratory Methods and Diagnosis. 18 ed Mosby, London, pp: 258-259.

Sundari, P.N., Wilfred, G. and Ramakrishna, B., (1997). Does oxidative protein damage play a role in the pathogenesis of carbon tetrachloride-induced liver injury in the rat? Biochimica et iophysica Acta 1362, 169- 176.

Trinder, P. (1959): Determination of blood glucose using 4- aminophenazone, J. Clin. Path. ,22: 246.

Uchiyama, M. and Mihara, M. (1978): Anal Biochem 86: 271-8.

Williamson EM, 2002. Major Herbs of Ayurveda. Churchill Livingstone, China, pp: 279-282. 


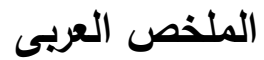

\section{التأثير المضاد للأكسدة لبذور مستخلص الجامبوزا الإيثانولي ضد رابع كلوريد الكريون الأي يسبب التسمم الكلوي في فئران التجارب}

تبحث هذه الدراسة تأثثر المستخلص الإيثانولي لبذور الجامبوزا ضد السمية الكلوية التي

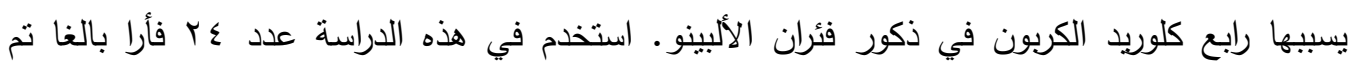

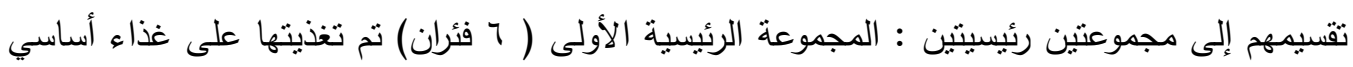

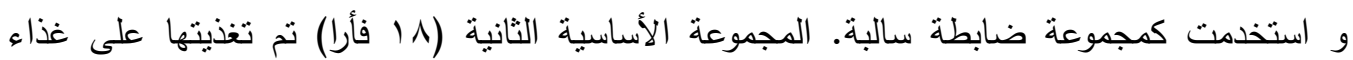

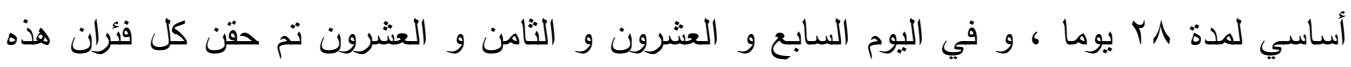

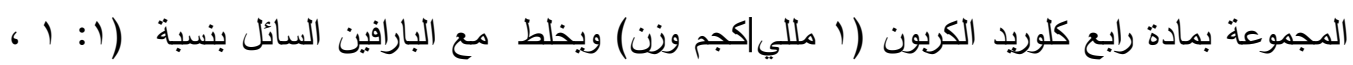

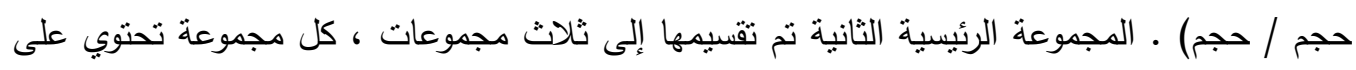

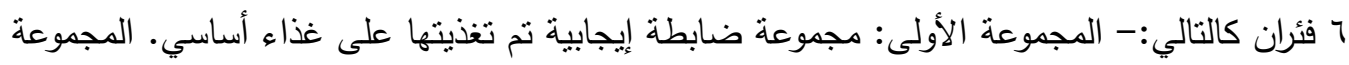

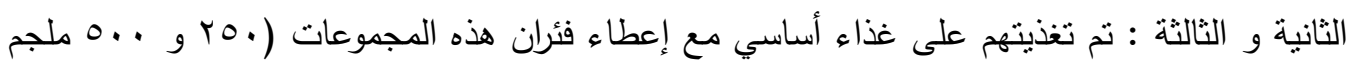
مستخلص ميثانولي لبذور الجامبوزاا كجم وزن) عن طريق الفم.

فى نهاية التجربة نم حساب التقديرات البيولوجية واخذت عينات الدم وفصل الكلى ووزنها ثم اجراء التحاليل البيوكمائية وكذلك الانزيمات المؤكسه متل MDA والانزيمات المضاد للأكسدة فى نسيج

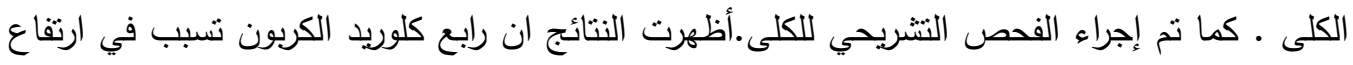

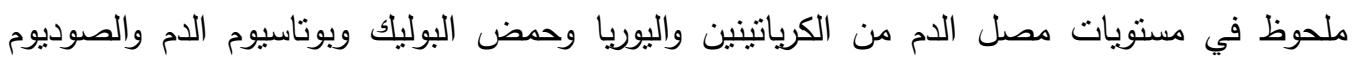

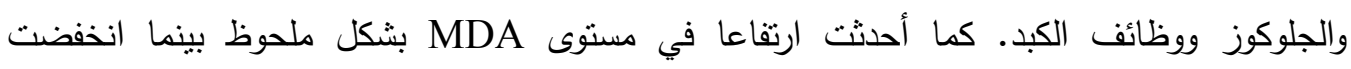

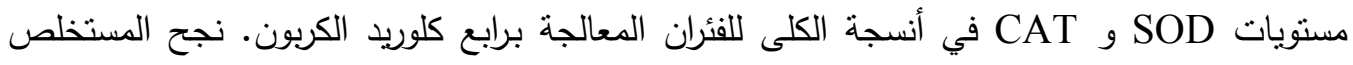
الإيثانولي لبذور الجامبوزا في تحسن أنسجة الكلى ـ أظهرت الدراسة أن تقليل المستخلص الإيثانولي

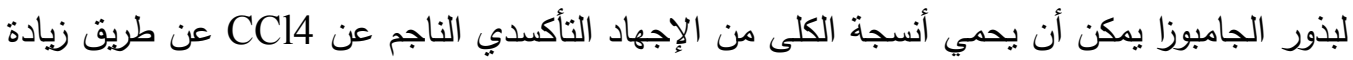
أنشطة الدفاع ضد الأكسدة.

الكلمات المفتاحية: الجامبوزا - الكلى- الكرياتينين- اليوريك اسيد -اليوريا -الكتاليز. 